http://dx.doi.org/10.11646/zootaxa.3847.1.1

http://zoobank.org/urn:lsid:zoobank.org:pub:C7BDD136-2686-4049-B395-684797B26406

\title{
Systematic revision of the family Hoplitomerycidae Leinders, 1984 (Artiodactyla: Cervoidea), with the description of a new genus and four new species
}

\author{
ALEXANDRA A. E. VAN DER GEER \\ Department of Geology, Naturalis Biodiversity Center, Leiden, the Netherlands. E-mail:alexandra.vandergeer@naturalis.nl
}

\begin{abstract}
Six species of the cervoid genus Hoplitomeryx are currently recognized from the Late Miocene sites of Gargano and Scontrone, in Italy: H. matthei Leinders, 1984, H. apruthiensis Mazza \& Rustioni, 2011, H. apulicus Mazza \& Rustioni, 2011, H. falcidens Mazza \& Rustioni, 2011, H. magnus Mazza \& Rustioni, 2011, and H. minutus Mazza \& Rustioni, 2011. These species are interpreted as members of an anagenetic series in these two localities, which are considered as part of the same bioprovince but with different geological ages. Comparative analysis of postcranial, dental, and cranial material from Hoplitomerycidae resulted in the reinterpretation of this current taxonomic arrangement. Two distinct genera can be distinguished. The new genus Scontromeryx is restricted to Scontrone (Early Tortonian) and is characterised by the presence of second upper and lower premolars and the absence of a nasal (median) horn. Hoplitomeryx is restricted to Gargano (Middle and/or Late Tortonian), and is characterized by the loss of the second premolar and presence of a nasal horn. Both genera are characterized by orbital appendages in some species, but the morphology of these appendages differs between the genera. Six species can be recognized for Scontromeryx gen. n.: S. minutus (type species), S. falcidens, $S$. apulicus, $S$. apruthiensis, $S$. magnus (new combinations) and the newly described $S$. mazzai sp. n.. Hoplitomeryx is represented by the $H$. matthei (type species) and 3 newly described species $H$. devosi sp. n., H. macpheei sp. n. and H. kriegsmani sp. n.. These two multispecies assemblages are best explained as independent adaptive radiations with the two genera as sister taxa. There is no evidence that the two localities were connected during the Late Miocene.
\end{abstract}

Key words: Gargano, gen. nov., Hoplitomeryx, insularity, Late Miocene, Scontrone, spp. nov.

\section{Introduction}

The palaeo-island Gargano (Apulia, southern Italy; Fig. 1) was inhabited by a strongly endemic vertebrate fauna during the Late Miocene, consisting of only ruminants, rodents, lagomorphs, insectivores, and an otter, besides birds, reptiles and amphibians (Freudenthal 1971, see also below). Although the composition of this remarkable fauna shows similarities with patterns recorded for the Pleistocene on other islands (e.g. De Vos 2006; De Vos et al. 2007), this fauna predates the latter faunas by at least a few million years and, presumably as a result of this longterm isolation, shows an extraordinary degree of endemism. The fauna is referred to as the Mikrotia fauna after its most abundant element (Freudenthal et al. 2013). A geologically younger, Late Villafranchian fauna, found in the same area is known as the Pirro Nord fauna.

The Mikrotia fauna of Gargano encompasses mammals, birds, reptiles, amphibians, and some invertebrates. The mammal fauna includes six endemic genera, about thirty endemic species, plus perhaps a few species with a wider distribution. The endemic genera are represented by deer-like ruminants (Hoplitomeryx Leinders, 1984), which form the focus of this revision, burrowing murine rodents (Mikrotia (Freudenthal, 1976), nomen novum for Microtia, see Freudenthal 2006), two galericine insectivores (Deinogalerix Freudenthal, 1972; Apulogalerix Masini and Fanfani, 2013; referred to as Galerix sp. or Parasorex sp. before 2013), giant dormice (Stertomys Daams and Freudenthal, 1985), and giant hamsters (Hattomys Freudenthal, 1985). The endemic species are an otter (Paralutra garganensis Willemsen, 1983), a dormouse (Dryomys apulus Freudenthal and Martín-Suárez, 2006) and two giant pikas (Prolagus imperialis Mazza, 1987; P. apricenicus Mazza, 1987). Perhaps not restricted to the Gargano are two hamster species (Neocricetodon Schaub, 1934 and Apocricetus Freudenthal, Mein and Martín- 
Scontromeryx and four of Hoplitomeryx. The smallest Hoplitomeryx individuals attained a size similar to that of the largest Deinogalerix, the giant Gargano erinaceid insectivore, both reaching a body mass of almost $10 \mathrm{~kg}$ (for Deinogalerix, see Lomolino et al. 2013; for the smallest Hoplitomeryx, see Appendix I). The largest Hoplitomeryx individuals on the other hand likely reached body masses in excess of $100 \mathrm{~kg}$ and were about twice as heavy as the largest Scontromeryx (Appendix I and table 2 respectively). These two (independent) multispecies assemblages are best explained as adaptive radiations (cladogenesis), as a result of ecological release and character displacement. The only known case of such a radiation in a ruminant taxon is the deer Candiacervus of the Late Pleistocene of Crete with several antler types and six different sizes of which the largest species was comparable to or slightly larger than $H$. kriegsmani and the smallest species slightly larger than $H$. devosi.

\section{Acknowledgments}

I wish to thank John de Vos, Jan van Tol and Jelle Reumer for critically reading earlier versions of the manuscript and for their constructive comments. I further would like to thank the following persons who helped to shape the present manuscript or previous versions in one way or the other, in alphabetical order, Matthijs Freudenthal, Lars van den Hoek Ostende, Christine Janis, Sjef Leinders, George Lyras and Jan van der Made. I am grateful to the editor, and to Roman Croitor and Loic Costeur for their constructive comments and suggestions which greatly improved the manuscript. Thanks are further due to the curators of hoplitomerycid material from Gargano, Reinier van Zelst (Naturalis Biodiversity Center, the Netherlands) and Federico Masini (University of Palermo, Italy) and from Scontrone, Paul Mazza (University of Florence, Italy) for kindly showing me the material and allowing me to study it. I am thankful to Boris Villier for casting the Hoplitomeryx humerus from Cava dell'Erba (Apricena, Italy; found by Mattia Gasparotto and Dawid Iurino), Eelco Kruidenier for making the photographs, and George Lyras and Anna Heijstee for the graphics.

\section{References}

Abbazzi, L., Benvenuti, M., Boschian, G., Dominici, S., Masini, F., Mezzabotta, C., Piccini, L., Rook, L., Valleri, G. \& Torre, D. (1996) Revision of the Neogene and Pleistocene of the Gargano region (Apulia, Italy). The marine and continental successions and the mammal faunal assemblages in an area between Apricena and Poggio Imperiale (Foggia). Memorie della Società Geologica Italiana, 51, 383-402.

Ballmann, P. (1973) Fossile Vögel aus dem Neogen der Halbinsel Gargano (Italien). Scripta Geologica, 17, 1-75.

Ballmann, P. (1976) Fossile Vögel aus dem Neogen der Halbinsel Gargano (Italien), Zweiter Teil. Scripta Geologica, 38, 1-59.

Bärmann, E.V. \& Rössner, G.E. (2011) Dental nomenclature in Ruminantia: towards a standard terminological framework. Mammalian Biology, 76, 762-768.

http://dx.doi.org/10.1016/j.mambio.2011.07.002

Butler, M. (1980) The giant erinaceid insectivore, Deinogalerix Freudenthal, from the upper Miocene of Gargano, Italy. Scripta Geologica, 57, 1-72.

Castaños, J., Castaños, P., Murelaga, X., Alonso-Olazabal, A., Ortega, L.A. \& Zuluaga, M.C. (2014) Osteometric analysis of scapula and humerus for Rangifer tarandus and Cervus elaphus: a contribution to cervid discrimination (Late Pleistocene, Southern Pyrenees). Acta Palaeontologica Polonica, in press. http://dx.doi.org/10.4202/app.2012.0027

Daams, R. \& Freudenthal, M. (1985) Stertomys laticrestatus, a new glirid (dormice, Rodentia) from the insular fauna of Gargano (Prov. of Foggia, Italy). Scripta Geologica, 77, $21-27$.

Damuth, J. (1990) Problems in estimating body masses of archaic ungulates using dental measurements. In: Damuth, J. \& MacFadden, B.J. (Eds.), Body size in mammalian paleobiology. Cambridge University Press, Cambridge, pp. 229-254.

Davis, E.B. \& Calède, J.J.-M. (2012) Extending the utility of artiodactyl postcrania for species-level identifications using multivariate morphometric analyses. Palaeontologica Electronica, 15 (1A), 1-122.

De Giuli, C. \& Torre, D. (1984) Species interrelationships and evolution in the Pliocene endemic faunas of Apricena (Gargano Peninsula-Italy). Geobios, 8, 379-383. http://dx.doi.org/10.1016/S0016-6995(84)80194-1

De Giuli, C., Masini, F., Torre, D. \& Boddi, V. (1987) Endemism and biochronological reconstructions: the Gargano case history. Bolletino della Società Paleontologica Italiana, 25, 267-76.

De Vos, J. (2006) Notes about parallels in the evolution of the Pleistocene cervids from Greece (Crete, Kassos and Karpathos), Japan (the Ryukyu-islands) and Philippines (Masbate). Hellenic Journal of Geosciences, 41, 127-40.

De Vos, J., Van den Hoek Ostende, L. \& Van den Bergh, G.D. (2007) Patterns in insular evolution of mammals: a key to island palaeogeography. In: Renema, W. (Ed.), Biogeography, Time and Place: Distributions, Barriers and Islands. Topics in Geobiology, 29. Springer, Dordrecht, pp. 315-345. 
Delfino, M., Böhme, M. \& Rook, L. (2007) First European evidence for transcontinental dispersal of Crocodylus (late Neogene of Southern Italy). Zoological Journal of the Linnean Society, 149, 293-307. http://dx.doi.org/10.1111/j.1096-3642.2007.00248.x

Delfino, M. (2002) Erpetofaune italiane del Neogene e del Quaternario. PhD thesis, Università degli Studi di Modena e Reggio Emilia, Modena, 382 pp.

Delfino, M. \& Rossi, M.A. (2013) Fossil crocodylid remains from Scontrone (Tortonian, Southern Italy) and the Late Neogene Mediterranean biogeography of crocodylians. Geobios, 46, 25-31. http://dx.doi.org/10.1016/j.geobios.2012.10.006

Fernández, H. \& Monchot, H. (2007) Sexual dimorphism in limb bones of ibex (Capra ibex L.): mixture analysis applied to modern and fossil data. International Journal of Osteoarchaeology, 17, 479-491. http://dx.doi.org/10.1002/oa.876

Fortelius, M., Eronen, J.T., Jernvall, J., Liu, L., Pushkina, D., Rinne, J., Tesakov, A., Vislobokova, I.A., Zhang, Z. \& Zhou, L. (2002) Fossil mammals resolve regional patterns of eurasian climate change during 20 million years. Evolutionary Ecology Research, 4, 1005-1016.

Freudenthal, M. (1971) Neogene vertebrates from the Gargano Peninsula, Italy. Scripta Geologica, 14, 1-10.

Freudenthal, M. (1972) Deinogalerix koenigswaldi nov. gen., nov. sp., a giant insectivore from the Neogene of Italy. Scripta Geologica, 14, 1-19.

Freudenthal, M. (1976) Rodent stratigraphy of some Miocene fissure fillings in Gargano (prov. Foggia, Italy). Scripta Geologica, 37, 1-23.

Freudenthal, M. (1985) Cricetidae (Rodentia) from the Neogene of Gargano (prov. of Foggia, Italy). Scripta Geologica, 77, 29-76.

Freudenthal, M. (2006) Mikrotia nomen novum for Microtia Freudenthal, 1976 (Mammalia, Rodentia). Journal of Vertebrate Paleontology, 26, 784. http://dx.doi.org/10.1671/0272-4634(2006)26[784:MNNFMF]2.0.CO;2

Freudenthal, M., Van den Hoek Ostende, L.W. \& Martín-Suárez, E. (2013) When and how did the Mikrotia fauna reach Gargano (Apulia, Italy)? Geobios, 46, 105-109. http://dx.doi.org/10.1016/j.geobios.2012.10.004

Freudenthal, M. \& Martín-Suárez, E. (2006) Gliridae (Rodentia, Mammalia) from the Late Miocene fissure filling Biancone 1 (Gargano, Province of Foggia, Italy). Palaeontologia Electronica, 9, 1-23.

Freudenthal, M. \& Martín-Suárez, E. (2010) The age of immigration of the vertebrate faunas found at Gargano (Apulia, Italy) and Scontrone (l'Aquila, Italy). Comptes Rendus Palevol, 9, 95-100. http://dx.doi.org/10.1016/j.crpv.2009.12.004

Freudenthal, M., Mein, P. \& Martín-Suárez, E. (1998) Revision of Late Miocene and Pliocene Cricetinae from Spain and France. Treballs del Museu de Geologia de Barcelona, 7, 11-93.

Giovinazzo, C., Altamura, S. \& Palombo, M.R. (2006) Determinazione della massa corporea nei ruminanti di media e piccolo taglia: un nuovo approccio metodologico. In: Fonda, G., Melis, R. \& Romano, R. (Eds.), Abstracts Giornate Paleontologia 2006, Trieste 8-10 Giugno. Università di Trieste, Trieste, pp. 39.

Geist, V. (1998) Deer of the World. Their evolution, behavior, and ecology. Stackpole Books, Mechanicsburg (PA), 421 pp.

Göhlich, U.B. \& Pavia, M. (2008) A new species of Palaeortyx (Aves: Galliformes: Phasianidae) from the Neogene of Gargano, Italy. Oryctos, 7, 95-108.

Gray, J.E. (1869) Notes on the families and genera of tortoises (Testudinata), and on the characters afforded by the study of their skulls. Proceedings of the Zoological Society of London, 165-225. http://dx.doi.org/10.111/j.1469-7998.1869.tb07312.x

Heintz, E. (1970) Les cervidés Villafranchiens de France et d'Espagne, Volume 1. Mémoires du Muséum National d'Histoire Naturelle nouvelle série, série C, tome XXII. Éditions du Muséum, Paris, 303 pp.

Hennekam, J. (2014) Dental variations in the island ruminant Hoplitomeryx. Unpublished MSc Thesis, Utrecht University, 33 pp.

Hue, E. (1907) Ostéométrie des Mammifêres. Musée Ostéologique, étude de la faune quaternaire, 2 vols. Schleicher, Paris, 186 pp.

Janis, C.M. (1988) An estimation of tooth volume and hypsodonty indices in ungulate mammals, and the correlation of these factors with dietary preference. In: Russell, D.E., Santoro, J.-P. \& Sigogneau-Russell, D. (Eds.), Teeth revisited: proceedings of the VIIth international symposium on dental morphology, Paris, 1986. Muséum National d'Histoire Naturelle, Paris, pp. 367-387.

Janis, C.M. (1990) Correlation of cranial and dental variables with body size in ungulates and macropodoids. In: Damuth, J. \& MacFadden, B.J. (Eds.), Body size in mammalian paleobiology. Cambridge University Press, Cambridge, pp. 255-300.

Janis, C.M. \& Scott, K.M. (1987) The interrelationships of higher ruminant families with special emphasis on the members of the Cervoidea. American Museum Novitates, 2893, 1-85.

Kappelman, J. (1988) Morphology and locomotor adaptations of the bovid femur in relation to habitat. Journal of Morphology, 198, 119-130. http://dx.doi.org/10.1002/jmor.1051980111

Kaup, J. (1829) Skizzierte Entwicklungs-Geschichte und Natürliches System der Europäischen Thierwelt. Vol. 1. C.W. Leske, Darmstadt/Leipzig, 203 pp.

Köhler, M. \& Moyà-Solà, S. (2004) Reduction of brain and sense organs in the fossil insular bovid Myotragus. Brain, 
Behaviour and Evolution, 63, 125-140.

http://dx.doi.org/10.1159/000076239

Laurenti, J.N. (1768) Specimen medicum, exhibens synopsin reptilium emendatam cum experimentis circa venena et antidota reptilium austriacorum. J.T. Trattnern, Vienna, $214 \mathrm{pp}$.

Leinders, J. (1984) Hoplitomerycidae fam. nov. (Ruminantia, Mammalia) from Neogene fissure fillings in Gargano (Italy). Scripta Geologica, 70, 1-68.

Lilje, K.E., Tardieu, C. \& Fischer, M.S. (2003) Scaling of long bones in ruminants with respect to the scapula. Journal of Zoological Systematics and Evolutionary Research, 41, 118-126. http://dx.doi.org/10.1046/j.1439-0469.2003.00207.x

Linnaeus, C. (1758) Systema naturae per regna tria naturae, secundum classes, ordines, genera, species, cum characteribus, differentiis, synonymis, locis. Tomus I. Editio decima, reformata. Laurence Salvius, Holmiae (= Stockholm), 824 pp.

Loison, A., Gaillard, J.-M., Pélabon, C. \& Yoccoz, N.G. (1999) What factors shape sexual size dimorphism in ungulates? Evolutionary Ecology Research, 1, 611-633.

Lomolino, M.V., Van der Geer, A.A., Lyras, G.A., Palombo, M.R., Sax, D.F. \& Rozzi, R. (2013) Of mice and mammoths: generality and antiquity of the island rule. Journal of Biogeography, 40, 1427-1439. http://dx.doi.org/10.1111/jbi.12096

Martin, R. (1980) Body mass and basal metabolism of extinct mammals. Comparative Biochemistry and Physiology, 66, 307-314. http://dx.doi.org/10.1016/0300-9629(80)90167-X

Martinez, J.-N. \& Sudre, J. (1995) The astragalus of Paleogene artiodactyls: comparative morphology, variability and prediction of body mass. Lethaia, 28, 197-209. http://dx.doi.org/10.1111/j.1502-3931.1995.tb01423.x

Masini, F. \& Fanfani, F. (2013) Apulogalerix pusillus nov. gen., nov. sp., the small-sized Galericinae (Erinaceidae, Mammalia) from the "Terre Rosse" fissure filling of the Gargano (Foggia, South-Eastern Italy). Geobios, 46, 89-104. http://dx.doi.org/10.1016/j.geobios.2012.10.008

Matsumoto, H. (1926) On some new fossil Cervicorns from Kazusa and Liukiu. Scientific Report of Tohoku Imperial University, Series 2 (Geology), 10, 21-23.

Matsumoto, Y. \& Otsuka, H. (2000) Morphotypes of fossil deer (Cervus astylodon) and its miniaturization process. Tropics, 10 , $145-154$.

Mayet, L. (1908) Étude des mammifères miocènes des sables de l'Orléanais et des faluns de la Touraine. Annales de Université de Lyon, nouvelle série, 24, 1-336.

Mazza, P. (1987) Prolagus apricenicus and Prolagus imperialis: two new Ochotonids (Lagomorpha, Mammalia) of the Gargano (Southern Italy). Bollettino della Società Geolologica Italiana, 26, 233-243.

Mazza, P.P.A. (2013) The systematic position of Hoplitomerycidae (Ruminantia) revisited. Geobios, 46, 33-42. http://dx.doi.org/10.1016/j.geobios.2012.10.009

Mazza, P. \& Rustioni, M. (1996) The Turolian fossil Artiodactyls from Scontrone (Abruzzo, Central Italy) and their paleoecological and paleoenvironmental implications. Bollettino della Società Paleontologica Italiana, 35, 93-106.

Mazza, P. \& Rustioni, M. (1999) Dental characters of the Turolian fossil artiodactyls from Scontrone (Abruzzo, Central Italy). In: Mayhall, J. \& Heikkinen, T. (Eds.), Proceedings of the 11th International Symposium on Dental Morphology, 26-30 August 1998, Oulu (Finland). Oulu University, Oulu, pp. 300-309.

Mazza, P. \& Rustioni, M. (2008) Processes of island colonization by Oligo-Miocene land mammals in the central Mediterranean: new data from Scontrone (Abruzzo, Central Italy) and Gargano (Apulia, Southern Italy). Palaeogeography, Palaeoclimatology, Palaeoecology, 267, 208-215. http://dx.doi.org/10.1016/j.palaeo.2008.06.018

Mazza, P.P.A. \& Rustioni, M. (2011) Five new species of Hoplitomeryx from the Neogene of Abruzzo and Apulia (central and southern Italy) with revision of the genus and of Hoplitomeryx matthei Leinders, 1983. Zoological Journal of the Linnean Society, 163, 1304-1333. http://dx.doi.org/10.1111/j.1096-3642.2011.00737.x

Meijer, H. (2013) A peculiar anseriform (Aves: Anseriformes) from the Miocene of Gargano (Italy). Comptes Rendus Palevol, 13, 19-26. http://dx.doi.org/10.1016/j.crpv.2013.08.001

Nowak, R.M. (1999) Walker's Mammals of the World. The Johns Hopkins University Press, Baltimore and London, 1936 pp.

O'Leary, M.A. \& Gatesy, J. (2008) Impact of increased character sampling on the phylogeny of Cetartiodactyla (Mammalia): combined analysis including fossils. Cladistics, 24, 397-442. http://dx.doi.org/10.1111/j.1096-0031.2007.00187.x

Patacca, E., Scandone, P. \& Mazza, P. (2008) Oligocene migration path for Apulia macromammals: the Central-Adriatic bridge. Bollettino della Società Geologica Italiana, 127, 337-355.

Patacca, E., Scandone, P. \& Carnevale, G. (2013) The Miocene vertebrate-bearing deposits of Scontrone (Abruzzo, Central Italy). Stratigraphic and paleoenvironmental analysis. Geobios, 46, 5-23. http://dx.doi.org/10.1016/j.geobios.2012.11.001

Pavia, M. (2013) The Anatidae and Scolopacidae (Aves: Anseriformes, Charadiiformes) from the late Neogene of Gargano, Italy. Geobios, 46, 43-48.

http://dx.doi.org/10.1016/j.geobios.2012.10.013

Peterson, R.O., Vucetich, J.A., Beyer, D., Schrage, M. \& Räikkönen, J. (2011) Phenotypic variation in moose: the island rule 
and the moose of Isle Royale. Alces, 47, 125-133.

Puputti, A.-K. \& Niskanen, M. (2008) The estimation of body weight of the reindeer (Rangifer tarandus L.) from skeletal measurements: preliminary analyses and application to archaeological material from 17th- and 18th-century northern Finland. Environmental Archaeology, 13, 153-164. http://dx.doi.org/10.1179/174963108X343272

Radinsky, L.B. (1984) Basicranial axis length v. skull length in analysis of carnivore skull shape. Biological Journal of the Linnean Society, 22, 31-41.

Ravosa, M.J. \& Ross, C.F. (1994) Craniodental allometry and heterochrony in two howler monkeys: Alouatta seniculus and A. palliata. American Journal of Primatology, 33, 277-299.

Rustioni, M., Mazza, P., Azzaroli, A., Boscagli, G., Cozzini, F., Di Vito, E., Masseti, M. \& Pisanò, A. (1992) Miocene Vertebrate remains from Scontrone, National Park of Abruzzi, Central Italy. Rendiconti della Classe Scienze Fisiche, Matematiche e Naturali dell'Accademia dei Lincei, 9, 227-237.

Ruiz Bustos, A., Sesé, C., Dabrio, C., Peña, J.A. \& Padial, J. (1984) Geología y Fauna de micromamíferos del nuevo yacimiento del Plioceno inferior de Gorafe-A (Depresión de Guadix-Baza, Granada). Estudios Geologicos, 40, $231-241$.

Schaub, S. (1934) Über einige fossile Simplicidentaten aus China und der Mongolei. Abhandlungen der Schweizerischen palaeontologischen Gesselschaft, Zurich, 54, 1-40.

Scopoli, J.A. (1777) Introductio ad historiam naturalem, sistems genera lapidum, plantarum et animalium hactenus detecta, caracteribus essentialibus donata, in tribus divisa, surinde ad leges naturae. Wolfgang Gerle, Pragae (= Prague), $541 \mathrm{pp}$.

Scott, W.B. (1885) Cervalces americanus, a fossil moose, or elk, from the Quaternary of New Jersey. Proceedings of the Academy of Natural Sciences of Philadelphia, 37, 181-202.

Scott, K.M. (1985) Allometric trends and locomotor adaptations in the Bovidae. Bulletin of the American Museum of Natural History, 179, 197-288.

Scott, K.M. (1990) Postcranial dimensions of ungulates as predictors of body mass. In: Damuth, J. \& MacFadden, B.J. (Eds.), Body size in mammalian paleobiology. Cambridge University Press, Cambridge, pp. 301-336.

Shea, B.T. (1983) Size and diet in the evolution of African ape craniodental form. Folia Primatologica, 40, 32-68.

Simpson, G.G. (1931) A new classification of mammals. Bulletin of the American Museum of Natural History, 59, $258-293$.

Stanley, S.M. (1978) Chronospecies' longevities, the origin of genera, and the punctational model of evolution. Paleobiology, 4, 26-40.

Szaniawski, A. (1966) Osteologische Untersuchungen über den Rothirsh in Polen. Acta Theriologica, 10, $195-267$.

Van den Hoek Ostende, L.W., Meijer, H.J.M. \& Van der Geer, A.A.E. (2009) A bridge too far. Comment on "Processes of island colonization by Oligo-Miocoene land mammals in the central Mediterranean: New data from Scontrone (Abruzzo, Central Italy) and Gargano (Apulia, Southern Italy)" by P.P.A. Mazza and M. Rustioni. Palaeogeography, Palaeoclimatology, Palaeoecology, 279, 128-130.

Van der Geer, A.A.E. (1999) On the astragalus of the Miocene endemic deer Hoplitomeryx from the Gargano (Italy). In: Reumer, J.W.F. \& de Vos, J. (Eds.), Elephants have a Snorkel! Papers in honour of P.Y. Sondaar. Deinsea, 7. Natuurmuseum Rotterdam, Rotterdam, pp. 325-336.

Van der Geer, A.A.E. (2005) The postcranial of the deer Hoplitomeryx (Mio-Pliocene; Italy): another example of adaptive radiation on Eastern Mediterranean Islands. Monografies de la Societat d'Historia Natural de les Balears, 12, 325-336.

Van der Geer, A.A.E. (2008) The effect of insularity on the Eastern Mediterranean early cervoid Hoplitomeryx: the study of the forelimb. Quaternary International, 182, 145-159. http://dx.doi.org/10.1016/j.quatint.2007.09.021

Van der Geer, A.A.E. (2014) Parallel patterns and trends in functional structures in extinct island mammals. Integrative Zoology, 9, 167-182. http://dx.doi.org/10.1111/1749-4877.12066

Van der Geer, A.A.E., De Vos, J., Lyras, G.A. \& Dermitzakis, M. (2006) New data on the Pleistocene Cretan deer Candiacervus sp. II (Mammalia, Cervinae). In: Kahlke, R.-D., Maul, L.C. \& Mazza, P. (Eds.), Late Neogene and Quaternary biodiversity and evolution: regional developments and interregional correlations. Courier Forschungsinstitut Senckenberg, 256. Vol. 1. Schweizerbart, Stuttgart, pp. 131-137.

Van der Geer, A.A.E., Lyras, G.A., De Vos, J. \& Drinia, H. (2013) Morphology of articular surfaces can solve a phylogenetic issue: one instead of two ancestors for Candiacervus. Zitteliana Reihe B: Abhandlungen der Bayerischen Staatssammlung für Palaeontologie und Geologie, 31, 33-34.

Villier, B. (2012) The anatomy of Deinogalerix and systematics of the Galericini. PhD thesis, Università degli Studi di Torino, Turin, $278 \mathrm{pp}$.

Villier, B., Van den Hoek Ostende, L.W., De Vos, J. \& Pavia, M. (2013) New discoveries on the giant hedgehog Deinogalerix from the Miocene of Gargano (Apulia, Italy). Geobios, 46, 63-75. http://dx.doi.org/10.1016/j.geobios.2012.10.001

Viret, J. \& Zapfe, H. (1952) Sur quelques Soricidés miocènes. Eclogae geologicae Helvetiae, 44, 411-426.

Willemsen, G.F. (1983) Paralutra garganensis sp. nov. (Mustelidae, Lutrinae), a new otter from the Miocene of Gargano, Italy. Scripta Geologica, 72, 1-8.

Zeder, M.A. (2006) Reconciling rates of long-bone fusion and tooth eruption and wear in sheep (Ovis) and goat (Capra). In: Ruscillo, D. (Ed.), Ageing and sexing animals from archaeological sites. Oxbow Press, Oxford, pp. 87-118.

Zeder, M.A. \& Lapham, H.A. (2010) Assessing the reliability of criteria used to identify postcranial bones in sheep, Ovis, and goats, Capra. Journal of Archaeological Science, 37, 2887-2905.

http://dx.doi.org/10.1016/j.jas.2010.06.032 